\title{
Nucleotide sequence of a mouse cDNA encoding the non-histone chromosomal high mobility group protein-2 (HMG-2)
}

\author{
Friederike Stolzenburg, Erika Dinkl and Friedrich Grummt \\ Institut für Biochemie, Universität Würzburg, D-8700 Würzburg, Germany
}

Submitted August 20, 1992

Recently similarities between particular transcription factors and the nonhistone chromatin proteins HMG1/2 (1) has been reported. Among these factors are the human upstream binding factor hUBF (2), the mammalian testes-determining factor SRY (3), the lymphoid enhancer-binding factor LEF-1 (4), and the T cellspecific factor TCF-1 (5). The regions of homology between these transcription factors and HMG-1/2 proteins are designated HMGboxes and it is thought that they represent DNA binding domains (2). There are also evidences that HMG-1/2 may play a role in DNA replication (6), chromatin assembly (7) and as general transcription factors for RNA polymerase II (8).

We have cloned a cDNA from mouse cells which apparently encodes the murine HMG-2 gene. A protein with an apparent molecular weight of $30 \mathrm{kD}$ was purified to homogenity by conventional and DNA affinity chromatography. For DNA affinity chromatography a double stranded oligonucleotide derived from the nontranscribed spacer of the murine rDNA repeat was used. V-8 protease digestion and subsequent peptide sequencing of two peptides with a length of 15 and 13 amino acid residues, respectively, revealed $100 \%$ homology to HMG-2 proteins of pig and human. Two cDNA clones were isolated from a cDNA library derived from mouse PCC4 teratocarcinoma cells (Stratagene Corp., La Jolla, CA). Clones were identified by hybridization with an oligonucleotide probe based on the protein sequence. Sequence analysis of one insert revealed a cDNA of $847 \mathrm{bp}$ in length containing a $135 \mathrm{bp} 5^{\prime}$ untranslated region, an open reading frame of $618 \mathrm{bp}$, and a $94 \mathrm{bp} \mathrm{3'}$ untranslated region. The translated protein sequence shows a high degree of similarity to published porcine (9), human (10) and chicken (11) HMG-2 proteins (Figure 1) and to a lesser extend similarities to HMG-1 proteins from mouse (12) and other species (Table 1). Thus it seems highly probable that this clone represents the murine HMG-2 gene.

\section{REFERENCES}

1. Johns,E.W. (1982) In, The HMG chromosomal proteins. Academic Press, N.Y. p. 251.

2. Jantzen,H.-M. et al. (1990) Nature 344, 830-836.

3. Sinclair,A.H. et al.(1990) Nature 346, 240-244.

4. Travis,A. et al. (1991) Genes Dev. 5, 880-894.

5. van de Wetering,M. et al. (1991) EMBO J. 10, 123-132.

6. Bonne-Andrea,C. et al. (1984) EMBO J. 3, 1193-1199.

\%. Kohlstaedt,L.A. et al. (1986) J. Biol. Chem. 262, 524-526.

8. Singh,J. and Dixon,G.H. (1990) Biochemistry 29, 6295-6302.

9. Shirakawa,H. et al. (1991) Biochemistry 29, 4419-4423.

10. Majumdar,A. et al. (1991) Nucleic Acids Res. 19, 6643.

11. Sparrow,D.B. and Wells,J.R.E. (1992) Gene 114, 289-290.

12. Yotov,W.V. and St-Arnaud,R. (1992)Nucleic Acids Res. 20,3516.

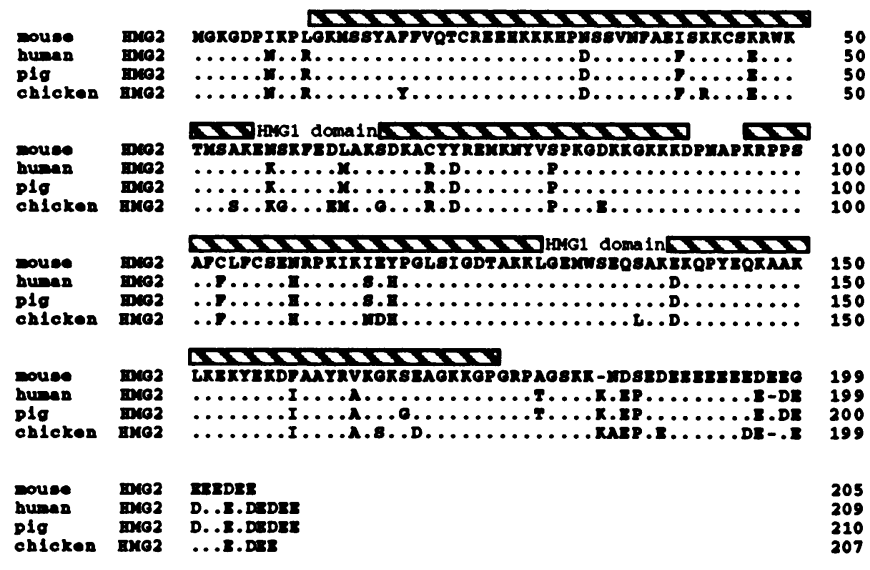

Figure 1. Sequence similarities between mouse, human, porcine and chicken HMG2 proteins. Non identical residues and the location of the HMG boxes are indicated.

Table 1. Nucleotide and amino acid sequence comparison between the mouse HMG2 sequence and HMG2 and HMG1 genes and proteins from other species

\begin{tabular}{lllll}
\hline Species & $\begin{array}{l}\text { Gene/ } \\
\text { Protein }\end{array}$ & $\begin{array}{l}\text { Identity of } \\
\text { nucleotides } \\
\text { coding region }\end{array}$ & $\begin{array}{l}\text { amino acid } \\
\text { identity }\end{array}$ & $\begin{array}{l}\text { amino acid } \\
\text { similarity }\end{array}$ \\
\hline mouse & HMG2 & $100 \%$ & $100 \%$ & $100 \%$ \\
human & HMG2 & $87 \%$ & $85 \%$ & $93 \%$ \\
pig & HMG2 & $87 \%$ & $86 \%$ & $93 \%$ \\
chicken & HMG2 & $81 \%$ & $82 \%$ & $92 \%$ \\
mouse & HMG1 & $73 \%$ & $74 \%$ & $84 \%$ \\
rat & HMG1 & $72 \%$ & $73 \%$ & $83 \%$ \\
human & HMG1 & $74 \%$ & $74 \%$ & $84 \%$ \\
pig & HMG1 & $74 \%$ & $74 \%$ & $74 \%$ \\
bovine & HMG1 & $75 \%$ & $74 \%$ & $84 \%$ \\
\hline
\end{tabular}

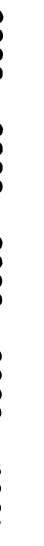

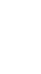

